\title{
Involvement of Distinct Pioneer Neurons in the Formation of Layer-Specific Connections in the Hippocampus
}

\author{
Hans Supèr, Albert Martínez, José A. Del Río, and Eduardo Soriano \\ Department of Animal and Plant Cell Biology, Faculty of Biology, University of Barcelona, Barcelona 08028, Spain
}

During neural development, specific recognition molecules provide the cues necessary for the formation of initial projection maps, which are reshaped later in development. In some systems, guiding cues for axonal pathfinding and target selection are provided by specific cells that are present only at critical times. For instance, the floor plate guides commissural axons in the spinal cord, and the subplate is involved in the formation of thalamocortical connections. Here we study the development of entorhinal and commissural connections to the murine hippocampus, which in the adult terminate in nonoverlapping layers. We show that two groups of pioneer neurons, CajalRetzius cells and GABAergic neurons, form layer-specific scaf- folds that overlap with distinct hippocampal afferents at embryonic and early postnatal stages. Furthermore, at postnatal day 0 (P0)-P5, before the dendrites of pyramidal neurons develop, these pioneer neurons are preferential synaptic targets for hippocampal afferents. Birthdating analysis using 5'bromodeoxyuridine (BrdU) pulses showed that most such early-generated neurons disappear at late postnatal stages, most likely by cell death. Together with previous studies, these findings indicate that distinct pioneer neurons are involved in the guidance and targeting of different hippocampal afferents.

Key words: Cajal-Retzius cells; pioneer neurons; synapse formation; axonal guidance; anterograde tracers; mouse
The development of specific neural connections is a multifactorial process in which different recognition signals acting at sequential developmental stages provide the cues necessary for the development of axonal projections. Among these cues there are diff usible factors, such as netrins and semaphorins, as well as membraneanchored factors and extracellular matrix proteins. These initial connections are later reshaped and pruned by mechanisms such as neurotrophin signaling and neural activity (for review, see Katz and Shatz, 1996; Tessier-Lavigne and Goodman, 1996).

In both vertebrates and invertebrates, guiding cues for axonal pathfinding and target selection are often provided by specific transient cells, which are only present at critical times (Bentley and Keshishian, 1982). For instance, the cells in the floor plate releasing netrin-1 exert a chemoattractive influence on commissural axons in the spinal cord (Kennedy et al., 1994; Serafini et al., 1994), whereas the same factor exerts chemorepellent action on trochlear motor fibers (Colamarino and Tessier-Lavigne, 1995; Culotti and Kolodkin, 1996). In the forebrain, the subplate cells of the developing visual cortex are involved in the guidance of ingrowing thalamocortical fibers and in their later segregation into ocular dominance columns (McConnell et al., 1989; Ghosh et al., 1990; Ghosh and Shatz, 1992; Allendoerfer and Shatz, 1994). Similarly, a population of cells in the optic chiasm may be essen-

\footnotetext{
Received Oct. 7, 1997; revised March 20, 1998; accepted March 26, 1998.

This study was supported by grants from Comisión Interministerial de Ciencia y Tecnología, Spain (SAF94-743, SAF96-1356-E, and SAF98-106), Dirección General de Investigacion Científica y Tecnológica (P.M.95-102), and Comissiò Interdepartamentol de Recerca i Tecnología (GR94-534) to E.S. and J.A.D.R. and from The Ramón Areces Foundation and the International Institute for Research in Paraplegia to E.S. and by a European Community fellowship to H.S. We thank G. Raisman (London), R. Rycroft (Barcelona), and H. B. M. Uylings (Amsterdam) for critical reading of an earlier version of this manuscript and P. Somogyi (Oxford) for the gift of GABA-9 antibody.

Correspondence should be addressed to Dr. Eduardo Soriano, Department of Animal and Plant Cell Biology, Faculty of Biology, University of Barcelona, Diagonal 645, Barcelona 08028, Spain.

Copyright (C) 1998 Society for Neuroscience $\quad 0270-6474 / 98 / 184616-11 \$ 05.00 / 0$
}

tial for the ingrowth and decussation of retinal axons (Sretavan, 1993; Wang et al., 1995).

One important feature of many regions of the adult brain is that neural connections are highly laminated with different groups of axons innervating specific target layers. In the hippocampus, for instance, the main afferent systems terminate in a characteristic nonoverlapping manner, with entorhinal fibers innervating outer pyramidal cell dendrites in the stratum lacunosum-moleculare and with commissural/associational fibers terminating in the stratum radiatum and stratum oriens. A similarly segregated distribution of hippocampal afferents occurs in the dentate gyrus, with entorhinal fibers innervating the outer molecular layer and with commissural/associational fibers terminating in the inner molecular layer (Blackstad, 1956; Raisman et al., 1965; HjorthSimonsen and Jeune, 1972; Amaral and Witter, 1995). Little is known about the factors that govern the generation of such a precise pattern of layer-specific connections during development. It has been suggested that the pattern of hippocampal innervation is independent of temporal factors such as the order of fiber arrival (Frotscher and Heimrich, 1993). Also, we have shown previously that both entorhinal and commissural axons terminate in their specific target layers at embryonic stages, which suggests the presence of layer-specific cues at these stages (Supèr and Soriano, 1994). Using the organotypic coculture approach, we have shown recently that a population of hippocampal early neurons, the cells of Cajal-Retzius, is essential for the ingrowth of entorhinal axons under these conditions in vitro (Del Río et al., 1997). Further, we have identified the reelin gene, which encodes an extracellular protein highly expressed in Cajal-Retzius cells (D'Arcangelo et al., 1995, 1997; Hirotsune et al., 1995; Ogawa et al., 1995), as one of the factors regulating the growth of entorhinal afferents (Del Río et al., 1997).

In the present study, we have analyzed the development of entorhinal and commissural/associational afferents to the mouse hippocampus in vivo. We found that, at the time of ingrowth, 
these developing afferents are spatially related with specific populations of hippocampal early neurons, which are arranged in specific laminae. Furthermore, at perinatal stages, hippocampal afferents establish preferential synaptic contacts with these layer-specific early neurons. Together with the above studies, such a precise sequence of developmental events indicates that these transient early neurons provide the laminar cues necessary for the targeting of hippocampal afferents, which constitutes a mechanism by which layer-specific neural connections can be specified. On the basis of their early neurogenesis and maturation and their participation in the formation of hippocampal connections, we regard these early neurons as pioneer cells.

\section{MATERIALS AND METHODS}

Tracing studies. Time-pregnant mice (NMRI strain) were obtained from IFFA Credo (Abresle, France). Embryos were removed by caesarean section after ether anesthesia of the mother and were stored in cooled PBS. Postnatal mice were anesthetized with ether or ice. Embryonic [embryonic day 15 (E15)-E19; $n=47$ ] and postnatal [postnatal day 0 (P0)-P10; $n=21]$ mice were transcardially perfused with $4 \%$ paraformaldehyde. After dissection, brains were injected with 1,1'-dioctadecyl$3,3,3^{\prime}, 3^{\prime}$-tetramethylindocarbocyanine perchlorate (DiI) or $4-(p$ dihexadecylaminostyryl)- $N$-methylquinoloinium iodide (DiQ) into the entorhinal cortex or the hippocampus as described (Supèr and Soriano, 1994). After 3-7 weeks in paraformaldehyde, 80- $\mu \mathrm{m}$-thick vibratome sections were obtained, counterstained with bisbenzimide, and coverslipped. For tracing associational connections, we injected $500-\mu \mathrm{m}-$ thick vibratome slices with DiI in the CA3 region; after 2 weeks, slices were sectioned as above. For the simultaneous labeling of pyramidal cells and entorhinal fibers, DiQ and 4-(4-dihexadecylaminostyryl)- $N$ methylpyridinium iodide (DiA) were injected in the entorhinal cortex and contralateral hippocampus. Sections were examined in an epifluorescence microscope.

Embryonic $(\mathrm{E} 19 ; n=7)$ and postnatal $(\mathrm{P} 0 ; n=14 ; \mathrm{P} 5 ; n=17)$ mice were also injected with crystals of biocytin in the entorhinal cortex or hippocampus. After ether anesthesia, mice were placed onto a stereotaxic frame mounted on chilled ice. After removal of the skin and parietal bone, a crystal of biocytin was positioned in the entorhinal cortex or hippocampus with the help of a glass micropipette. Eighteen to twenty-four hours later, the animals were perfused with paraformaldehyde, and their brains were dissected out. Older animals (P10, P21, and young-adult mice) were traced by iontophoresis of biocytin. After chloral hydrate anesthesia, mice were fixed to a stereotaxic frame, a glass micropipette (tip, 25-20 $\mu \mathrm{m}$ ) was positioned in the entorhinal cortex or dorsal hippocampus, and biocytin was injected (positive current; $7 \mathrm{sec}$ on-off cycle; $20-25 \mathrm{~min}$ ). After 1-2 d of survival, mice were perfused with $4 \%$ paraformaldehyde, and their brains were dissected out and post-fixed in the same solution. Coronal sections (50 $\mu \mathrm{m}$ thick) were obtained with a vibratome and incubated overnight with the avidinbiotin-peroxidase complex (ABC; Vector Laboratories, Burlingame, CA) diluted 1:200. After development with $0.03 \%$ diaminobenzidine (DAB) and $0.01 \%$ hydrogen peroxide in the presence of nickel (Del Río et al., 1997), sections were counterstained and coverslipped.

Immunocytochemistry. Embryos (E14-E18) and postnatal animals (P0-P45 and adults) were transcardially perfused with $4 \%$ paraformaldehyde (plus $0.25 \%$ glutaraldehyde for GABA immunostaining). Coronal vibratome sections ( $50 \mu \mathrm{m}$ thick) were immunostained using well characterized calretinin (Swant, Bellinzona, Switzerland), calbindin (Swant), and GABA (Incstar) antibodies raised in rabbits and the ABCperoxidase complex (Soriano et al., 1994; Del Río et al., 1995). Sections in which the primary antibody was omitted did not reveal immunolabeling. For double-labeling studies, sections were incubated with a mixture of goat anti-calretinin (Swant) and rabbit anti-GABA or -calbindin antibodies and then with Texas Red- and fluorescein-coupled secondary antibodies.

Double-labeling biocytin studies. E19 embryos, postnatal mice (P0$\mathrm{P} 21$ ), and adult animals were injected with biocytin in the entorhinal cortex or hippocampus as described above. After perfusion, the brains were sectioned with a vibratome $(50 \mu \mathrm{m})$. Biocytin was then visualized with the $\mathrm{ABC}$ reagent developed with $\mathrm{DAB}$-nickel (black reaction prod- uct); sections were then immunostained for neural antigens (calretinin, calbindin, or GABA), which were visualized with DAB (brown reaction product). In some cases, sections were incubated with Texas Redstreptavidin for biocytin and with fluorescein-conjugated antibodies for neural antigens.

5'-Bromodeoxyuridine studies. For the 5'-bromodeoxyuridine (BrdU) experiments, time-pregnant dams were injected with a single BrdU pulse at E10, E11, E12, E13, E15, or E16 $(n=2-3$ dams per age $)$. Offspring were killed at E18, P0, P15, P15, and P45 (Soriano and Del Río, 1991). After perfusion with paraformaldehyde, brains were fixed in Carnoy's solution, embedded in paraffin, and coronally sectioned at $15 \mu \mathrm{m}$. After DNA denaturation, sections were immunolabeled for BrdU as described, using a DAB-nickel-enhanced reaction (Soriano and Del Río, 1991), counterstained with hematoxylin, and coverslipped.

Cell counts. For all cell counts, the total number of immunoreactive (or BrdU-labeled) neurons present in the entire stratum lacunosum/moleculare, stratum radiatum, pyramidal layer, and stratum oriens of single sections (from the CA3 region to the subiculum) was counted in coronal sections of the dorsal hippocampus of mice aged P0, P5, P15, P21, and $\mathrm{P} 45$. Data were expressed as the total number of cells per section. All sections counted corresponded to equivalent rostrocaudal levels $[F, 1.5-$ 2.0, according to Slotnick and Leonard (1975)]. This procedure, i.e., counting the total number of cells in a section, avoids cell dilution attributable to the mediolateral and dorsoventral growth of the telencephalon (for details, see Del Río et al., 1995; Valverde et al., 1995). Crude cell counts were then corrected for rostrocaudal dilution by multiplying by a factor of rostrocaudal increase of the hippocampus (see Del Río et al., 1995) (P0, being 1; P5, ×1.3; P15, ×1.8; P21, ×2.2; and $\mathrm{P} 45, \times 2.3)$. Sections from two to four animals were counted at each stage (12-16 sections per age).

Electron microscopy studies. Postnatal mice (P0-P5) and adult animals were injected with biocytin as described above. Animals were then perfused with $4 \%$ paraformaldehyde and $0.2-1 \%$ glutaraldehyde in $0.12 \mathrm{M}$ phosphate buffer; their brains were sectioned in a vibratome and processed for the detection of biocytin with the $\mathrm{ABC}$ reagent as described above. For entorhinal injections, biocytin was developed with DAB-nickel, and the sections were subsequently immunostained for calretinin, which was visualized with DAB alone (Gulyás et al., 1993). Sections were then osmified and embedded in Araldite. Ultrathin sections were stained with lead citrate and examined in the electron microscope. For commissural injections, vibratome slices were developed with DAB to visualize biocytin, osmified, and embedded in Araldite. Ultrathin sections were then immunostained using the GABA-9 antibody and gold (10 nm)-coupled secondary antibodies as described (Somogyi et al., 1985). For the quantitative data, ultrathin sections mounted onto single slot grids were positioned in the stratum lacunosum-moleculare or stratum radiatum, and the microscope was moved at random over a given layer. Every synaptic contact formed by a biocytin-positive bouton was photographed and recorded. Two animals were used at each stage for either commissural and entorhinal injections (115-131 synapses harvested at each age).

Delimitation of layers. The laminar boundaries in the developing hippocampus were delimited according to the cytoarchitectonic criteria described in our previous studies (Soriano et al., 1994; Supèr and Soriano, 1994; Del Río et al., 1997) using Nomarski interference optics (in immunohistochemical preparations) or bisbenzimide staining (for DiI tracing). At embryonic and perinatal stages, the following layers were distinguished: ventricular zone, white matter (intermediate zone), stratum oriens (subplate zone), pyramidal cell layer (hippocampal plate), and stratum radiatum and stratum lacunosum-moleculare (both in the marginal zone). The embryonic white matter appeared as a fiber-rich layer located just above the ventricular layer. The stratum oriens was comprised between the white matter and the pyramidal cell layer, which at these stages (E15-E18) was five to eight cells thick. The stratum radiatum (inner marginal zone) was located just above the pyramidal layer and, at these stages, corresponded to the inner half of the marginal zone; the stratum radiatum was populated by many more cells than was the outer marginal zone. The stratum lacunosum-moleculare (outer marginal zone) was located between the stratum radiatum and the hippocampal fissure, approximately corresponding to the outer half of the marginal zone. 

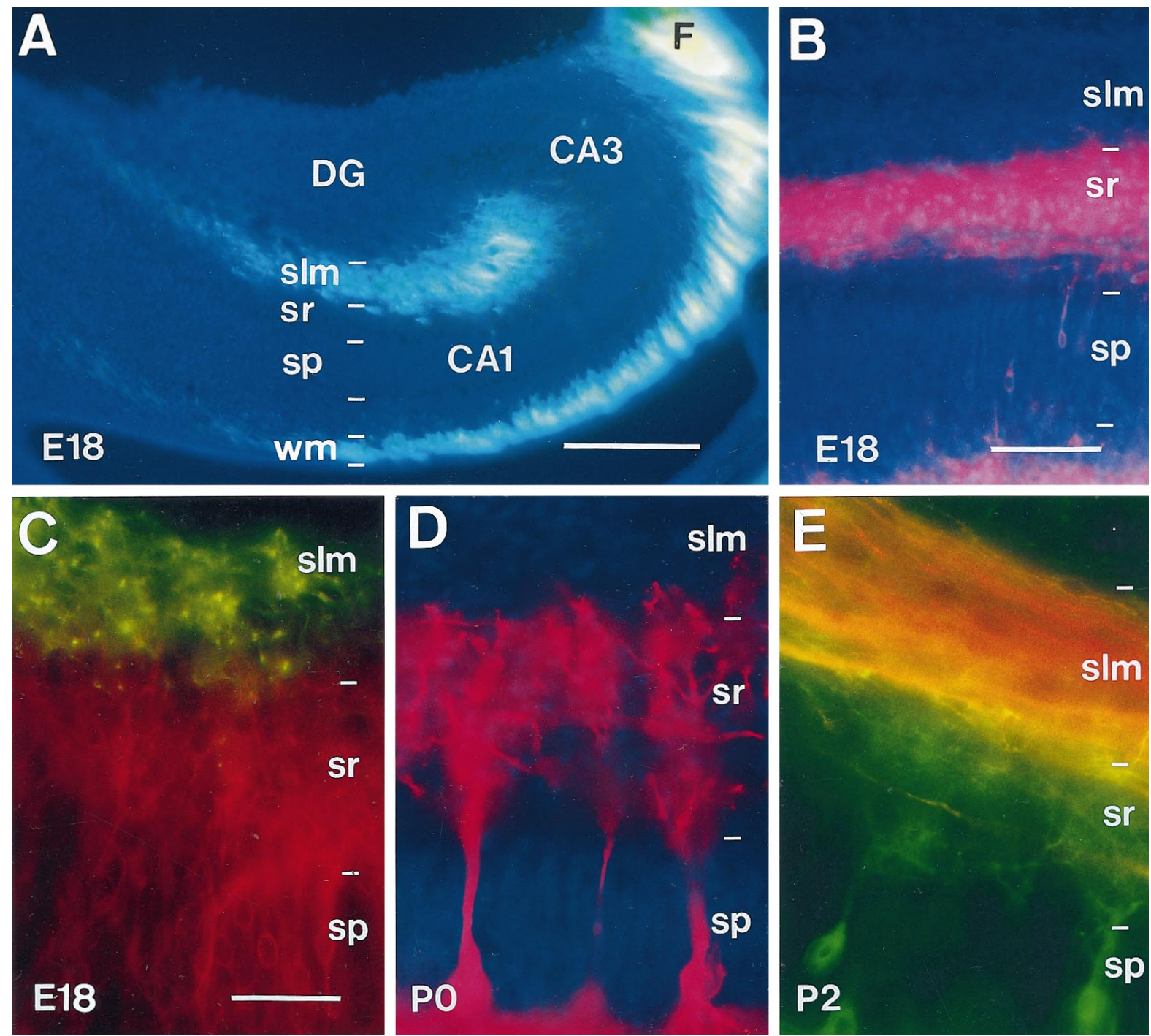

Figure 1. Layer-specific termination of developing connections in the hippocampus. $A$, Distribution of entorhinal fibers at E18 in the $s / m$ and in the $w m$, after an entorhinal injection of DiI. B, Distribution of associational fibers at E18 in the $s r$ of the CA1 region after an injection of DiI in the CA3 region. $C, E$, Visualization of anterogradely traced entorhinal fibers and retrogradely labeled pyramidal cells in the CA1 region at E18 and P2, showing entorhinal afferents running above pyramidal cell dendrites. In $C$, entorhinal axons were labeled with DiA ( green), and pyramidal neurons were labeled with DiQ (red); the reverse combination was used in $E$. D. Distribution of DiI-stained pyramidal cell apical dendrites at P0. Note that these dendrites terminate before the $\operatorname{slm}$. Sections in $A$ and $B$ are counterstained with bisbenzimide. Scale bars: $A, 250 \mu \mathrm{m} ; B, 100 \mu \mathrm{m} ; C-E, 50 \mu \mathrm{m}$. $C A 1, C A 3$, Hippocampal subfields; $D G$, dentate gyrus; $F$, fimbria; $s l m$, stratum lacunosum-moleculare; $s p$, stratum pyramidale; $s r$, stratum radiatum; $w m$, white matter.

\section{RESULTS}

\section{Developing hippocampal afferents are targeted in a layer-specific manner}

The development of hippocampal connections in the mouse was studied with injections of lipophilic dyes (DiI) and biocytin. In agreement with a previous study (Supèr and Soriano, 1994), entorhinal axons labeled after injections made in the entorhinal area reached the target hippocampus at embryonic day 15 (E15). One day later, entorhinal fibers grew selectively into the outer marginal zone (prospective stratum lacunosum-moleculare), where they arborized densely by E17-E19 (Fig. 1A). There was virtually no invasion of ingrowing entorhinal fibers into other hippocampal layers such as the stratum radiatum or the hilar region. Conversely, CA3-to-CA1 associational axons labeled after local DiI injections in the CA3 region were seen to terminate specifically in the inner marginal zone (future stratum radiatum) with no invasion of the stratum lacunosum-moleculare (Fig. 1B), as previously shown for commissural fibers (Supèr and Soriano, 1994). Thus, developing hippocampal afferents innervate their specific target layer from the very beginning without exuberant growth in inappropriate layers, indicating that cues allowing target-layer selection are present at these embryonic ages.

We next examined whether the dendrites of pyramidal neurons, the main targets of entorhinal and commissural/associational fibers in the adult, could play a role in such a guidance. Retrograde tracing experiments with DiI, however, showed that at E16-P2 the growing apical dendrites of pyramidal neurons terminated at the stratum radiatum and stratum lacunosummoleculare interphase, with no growth into the outer marginal zone, long before reaching the hippocampal fissure (Fig. 1D). Double-labeling retrograde and anterograde experiments with two lipophilic dyes confirmed that most entorhinal axons ran 
above pyramidal cell dendrites (Fig. $1 C, E$ ), indicating that positional cues for the targeting of entorhinal fibers are unlikely to be present in these dendrites. However, the dendrites of pyramidal neurons in the stratum radiatum could potentially be in a suitable position to influence or target commissural/associational fibers.

\section{Layer-specific arrangement of pioneer neurons in the hippocampus}

In the neocortex the subplate is involved in the development of thalamocortical connections (McConnell et al., 1989; Ghosh et al., 1990; Allendoerfer and Shatz, 1994). We next studied the developmental history of hippocampal pioneer neurons (Nowakowski and Rakic, 1979; Soriano et al., 1994) and their putative involvement in the formation of hippocampal circuits. From E15 to P5, two main subsets of pioneer neurons were found in the marginal zone of the hippocampus. Cajal-Retzius cells, identified using a calretinin antibody marker (Soriano et al., 1994; Del Río et al., 1995), were densely packed in the outer marginal zone or stratum lacunosum-moleculare (Fig. 2A,C). In contrast, GABA-positive neurons were located in the inner marginal zone or stratum radiatum (Fig. 2E). Most such GABA-positive neurons $(73 \%$ at $\mathrm{P} 0 ; n=612$ ) also displayed calbindin $28 \mathrm{~K}$, a more suitable antibody cell marker than GABA, immunoreactivity (Fig. 2B,D). Double immunolabeling confirmed that at perinatal stages CajalRetzius cells and GABA-positive or calbindin-positive neurons were distributed in distinct, nonoverlapping layers (Fig. $2 F$ ).

To investigate the birthdates of these pioneer neurons in the hippocampus, mouse embryos were labeled with a single-pulse injection of BrdU (Soriano and Del Río, 1991). At E18-P0, most BrdU-positive neurons born at E10-E12 were in the outer marginal zone or stratum lacunosum-moleculare and in the inner marginal zone or stratum radiatum (Figs. $2 G, 3 C$ ); they were also observed, to a lesser extent, in the subplate or stratum oriens. In contrast, the neurons in the pyramidal layer were primarily devoid of BrdU labeling after early BrdU injections at E10-E12 (Fig. 2G). Double immunostaining with calretinin and calbindin $28 \mathrm{~K}$ antibodies showed that most hippocampal neurons born at E10-E11 were Cajal-Retzius cells (Fig. $2 H$ ) and GABA-positive neurons (data not shown). Conversely, hippocampal pioneer neurons were unlabeled when BrdU injections were administered at E15-E16, which resulted in massive labeling of pyramidal neurons in both the CA3 and CA1 regions (Fig. 3C), in agreement with earlier studies reporting that pyramidal cell neurogenesis in the mouse hippocampus peaks by E14-E16 (Soriano et al., 1989). We therefore conclude that the hippocampal marginal zone, the prospective stratum lacunosum-moleculare and stratum radiatum, contains two different subsets of early-generated pioneer neurons arranged in a nonoverlapping manner.

\section{Pioneer neurons in the hippocampus are transient}

As counted from calretinin-immunostained sections, the number of Cajal-Retzius cells in the stratum lacunosum-moleculare decreased gradually between P5 and adult stages, mostly after P15 (Fig. 3A). Few calretinin-positive Cajal-Retzius cells could be observed in the adult stratum lacunosum-moleculare $(82 \%$ decrease respect to P5). During the period of disappearance, most Cajal-Retzius cells showed shrunken perikarya and atrophic dendrites, which are morphological correlates of neuronal death (Valverde and Facal-Valverde, 1987; Del Río et al., 1995). To substantiate the notion that Cajal-Retzius cells disappear by naturally occurring cell death, we counted the number of BrdUpositive cells generated at E10-E12 that are present in hippocam- pal sections from P0 onward. In the stratum lacunosummoleculare, we found a $60-79 \%$ decrease in the number of BrdU-labeled cells present at P45 compared with that at P0 (Figs. $2 J, 3 D)$, with most of this decrease occurring between P15 and adults (data not shown). A marked reduction, although less dramatic than that for Cajal-Retzius cells, was also noted for the GABA-positive neurons in the stratum radiatum, by cell counts made in both GABA- and BrdU-immunoreacted sections (Fig. $3 B, E)$. Such a decrease occurred mainly between P5 and P15. Consistent with the notion that many pioneer neurons die, we often observed at P5-P15 pyknotic cells exhibiting BrdU immunostaining (Fig. $2 I$ ) in the stratum radiatum and stratum lacunosum-moleculare, after BrdU injections administered at E10-E12. This observation demonstrates unequivocally that at least some early-generated neurons in the hippocampus disappear by cell death. We thus conclude that most pioneer neurons in the marginal zone of the hippocampus, in particular CajalRetzius cells, are transient and disappear by cell death at the end of postnatal development.

\section{Relationship of developing hippocampal afferents and pioneer neurons}

To investigate whether hippocampal pioneer neurons participate in the formation of hippocampal connections in vivo, we combined anterograde tracing of biocytin with immunostaining for pioneer cells. After injections of biocytin in the entorhinal cortex at E19-P5, the distribution of entorhinal axons in the stratum lacunosum-moleculare matched that of Cajal-Retzius cells (Fig. $4 A$ ). Often, single fibers impinged onto the dendrites and perikarya of clusters of Cajal-Retzius cells and silhouetted their shapes (Fig. 4B). Conversely, the earliest commissural axons labeled by biocytin injections in the contralateral hippocampus at P0-P5 were observed to run and arborize specifically in the stratum radiatum and stratum oriens, where they overlapped with the GABA/calbindin-positive neurons (Fig. 4D,E).

Similar populations of pioneer neurons were found in the late-formed dentate gyrus at perinatal stages. Thus, CajalRetzius cells were located in the outer half of the dentate molecular layer, close to the hippocampal fissure, and GABApositive neurons formed a tight band of neurons restricted to the inner molecular layer (Fig. 4C,G). Again, the first entorhinal afferents entering the dentate gyrus on $\mathrm{P} 0-\mathrm{P} 2$ were restricted to the outer molecular layer, where axons ran and intermingled in close apposition to dentate Cajal-Retzius cells (Fig. 4C). Similarly, ingrowing commissural fibers were restricted to the inner molecular layer, where they overlapped with the GABA-positive cells present in this target layer (Fig. $4 F, G$ ). Both in the hippocampus proper and in the dentate gyrus, the close relationship of developing afferent fibers and pioneer neurons seen at perinatal stages was progressively lost after P5, as the pioneer neurons disappear and the afferent connection systems mature (data not shown). We thus conclude that at the time of axon arrival and layer-specific invasion, developing hippocampal afferents are spatially related to distinct pioneer neurons.

\section{Hippocampal pioneer neurons are transient synaptic targets for developing afferents}

We next used electron microscopy to ascertain whether pioneer neurons could be synaptic targets for developing axons at perinatal stages. We used a double DAB reaction to identify entorhinal axons and calretinin-positive target Cajal-Retzius cells at the electron microscope. There are relatively few synaptic contacts in 

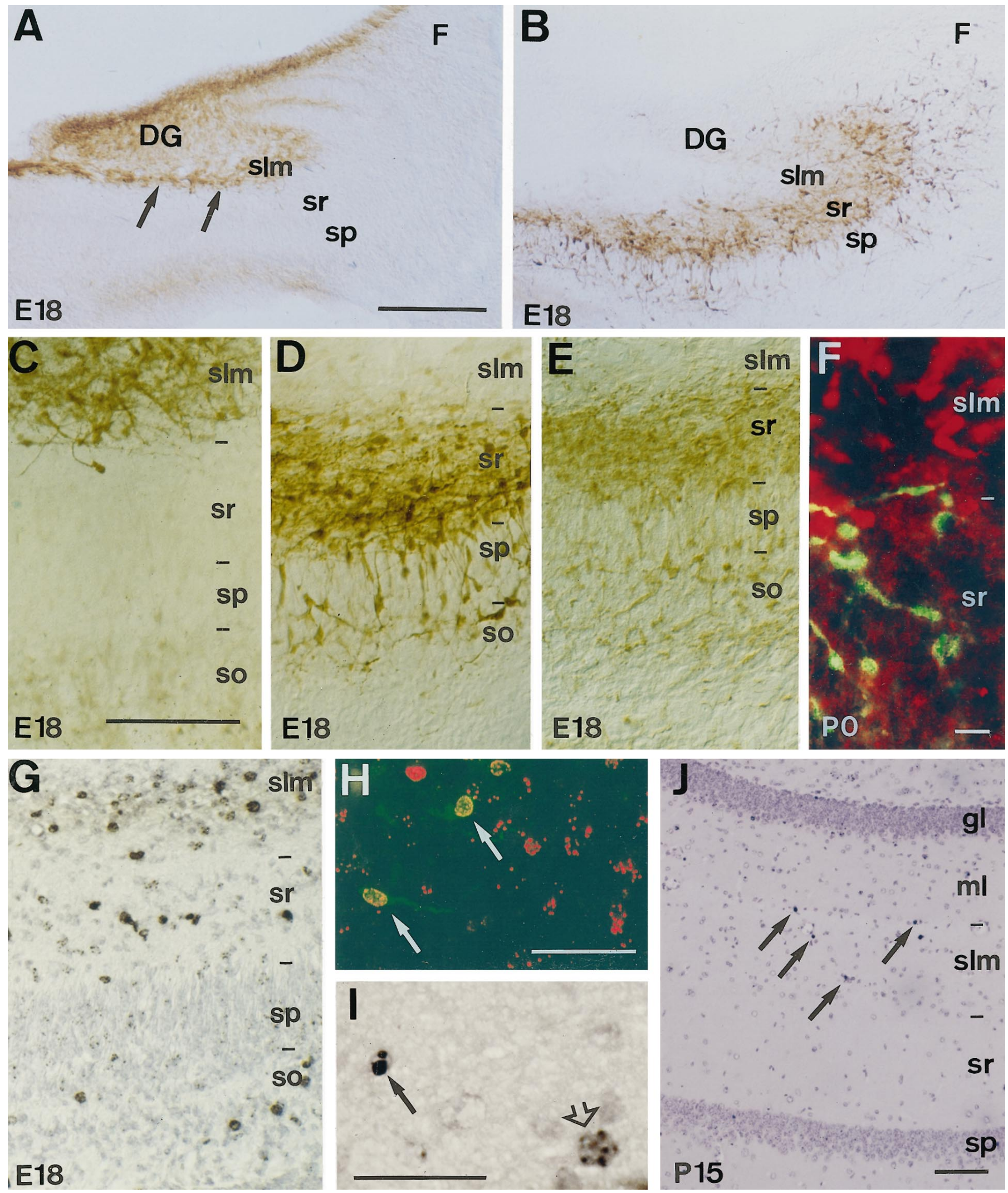

Figure 2. Distribution and neurogenesis of pioneer neurons in the hippocampus. $A, B$, Panoramic views of the hippocampus at E18 immunolabeled with calretinin and calbindin antibodies. In $A$, Cajal-Retzius cells (arrows), identified with calretinin antibodies, are located in the stratum lacunosummoleculare or outer marginal zone; the immature granule cells in the dentate gyrus also display weak calretinin immunolabeling. In contrast, calbindin-positive neurons $(B)$ are located in the stratum radiatum or inner marginal zone but not in the stratum lacunosum-moleculare. $C-E$, Higher views of the hippocampus at E18 showing the distinct laminar distributions of calretinin-positive Cajal-Retzius cells $(C)$ and calbindin- and GABA-immunoreactive neurons ( $D, E$, respectively). $F$, Double-immunofluorescence confocal photomicrograph showing (Figure legend continues) 
A

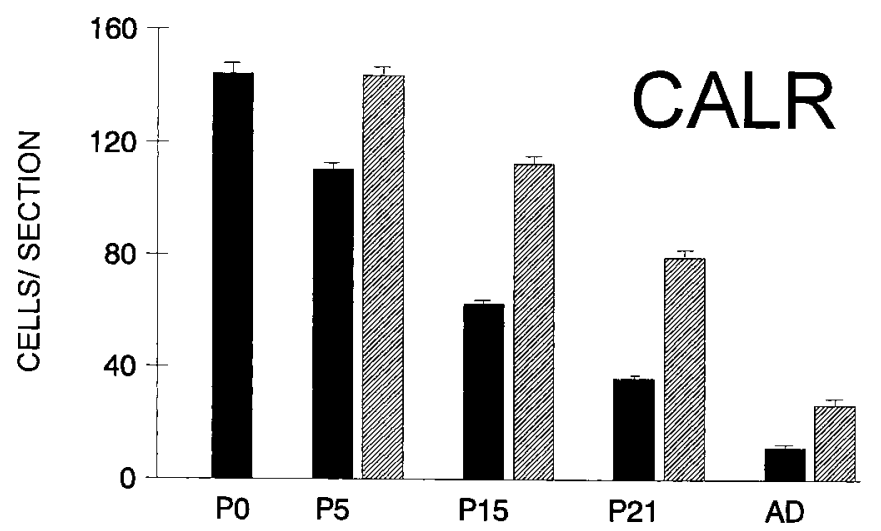

C

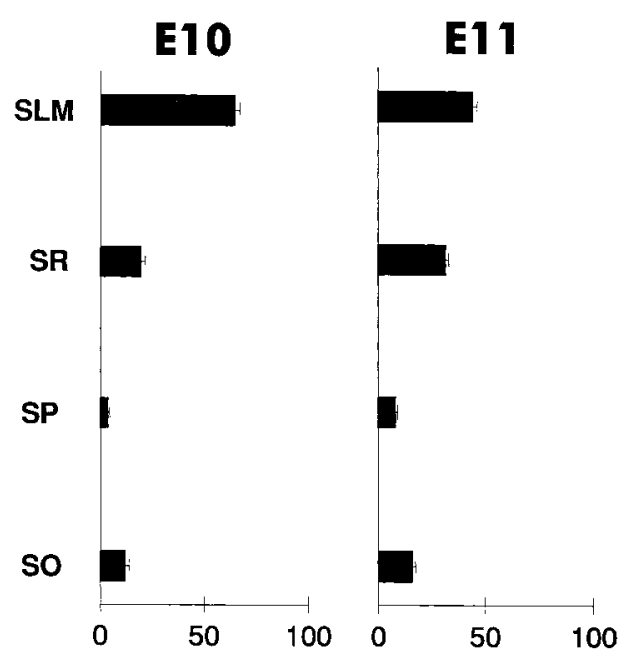

$\%$ BrdU+ Cells

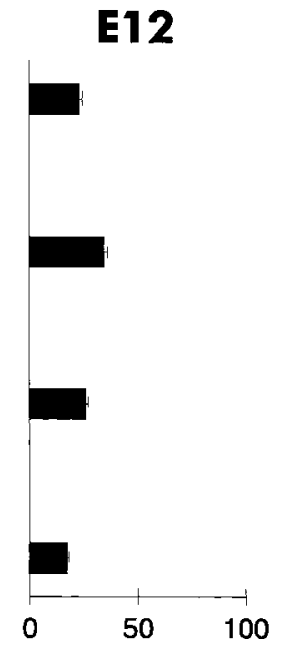

B

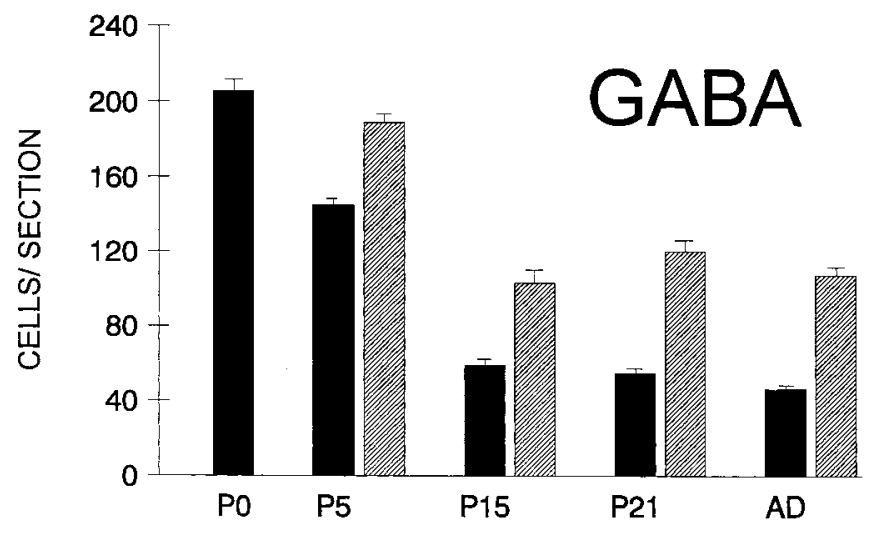

Figure 3. Quantitative analyses on the neurogenesis and fate of pioneer neurons in the hippocampus. Data are expressed as the number of labeled cells per section. $A, B$, Number of calretinin-positive Cajal-Retzius cells $(A)$ in the stratum lacunosum-moleculare and of GABA-positive neurons $(B)$ in the stratum radiatum at different postnatal ages (P0-P21) and in the adult. Solid bars are crude cell counts, whereas hatched bars are values corrected for a factor of cortical growth (see Materials and Methods). C, Laminar distribution of BrdU-positive cells at P0 after a BrdU pulse injection at E10, E11, E12, or E16. Pioneer neurons in the stratum radiatum and stratum lacunosum-moleculare are generated at E10-E12, whereas the far more numerous pyramidal neurons are born later. $D, E$, Comparison of the numbers of BrdU-positive cells in the stratum lacunosum-moleculare and stratum radiatum in littermates aged $\mathrm{P} 0$ and $\mathrm{P} 45$ after BrdU injections administered at E10, E11, and E12. Values at P45 are corrected for a factor of cortical growth as in $A$ and $B$ (** indicates $p \leq 0.01$; ANOVA, Scheffé's test). $A D$, Adult; $C A L R$, calretinin; $S L M$, stratum lacunosum-moleculare; $S O$, stratum oriens; $S P$, stratum pyramidale; $S R$, stratum radiatum.

the stratum lacunosum-moleculare at P0. In agreement with this, biocytin-labeled entorhinal axons were seen to run within this layer, sometimes in axonal bundles, and they displayed few differentiated axon terminals along their length. These presynaptic axon terminals showed accumulations of synaptic vesicles and established asymmetric synapses with both Cajal-Retzius cells (Fig. $5 A, B$ ) and other unlabeled profiles. At P0, up to $51 \%$ of entorhinal synaptic contacts observed in the stratum lacunosum-

\footnotetext{
nonoverlapping distribution of calretinin-positive Cajal-Retzius cells (red) and calbindin-positive neurons ( green) at P0. G, Distribution of BrdU-positive neurons in the E18 hippocampus after a BrdU pulse at E11. BrdU-immunoreactive cells (black) are mainly present in the stratum radiatum and stratum lacunosum-moleculare, as well as in the stratum oriens. Note that pyramidal neurons in the pyramidal layer are devoid of labeling after a BrdU pulse at E11. H, Confocal fluorescence photomicrograph showing BrdU labeling (red) of calretinin-positive Cajal-Retzius cells (green) in the stratum lacunosum-moleculare after a BrdU pulse at E11; arrows point to double-labeled cells. I, BrdU immunolabeling of a pyknotic cell (arrow) and a healthy neuron (open arrow) in the stratum lacunosum-moleculare at P15, after an injection of BrdU at E10. Sections in $G$ and $I$ are counterstained with hematoxylin. $J$, BrdU immunostaining of a section from a P15 hippocampus after a BrdU injection administered at E11. Note the dramatic decrease in the number of BrdU-positive cells (arrows) present in the stratum radiatum and stratum lacunosum-moleculare compared with that at E18 ( $G$ ). Scale bars: $A, B, 300 \mu \mathrm{m} ; C-E, G, 200 \mu \mathrm{m} ; F, 25 \mu \mathrm{m} ; H, J, 100 \mu \mathrm{m} ; I, 50 \mu \mathrm{m}$. $D G$, dentate gyrus; $F$, fimbria; gl, granular layer; $m l$, molecular layer; slm, stratum lacunosum-moleculare; $s o$, stratum oriens; $s p$, stratum pyramidale; $s r$, stratum radiatum.
} 

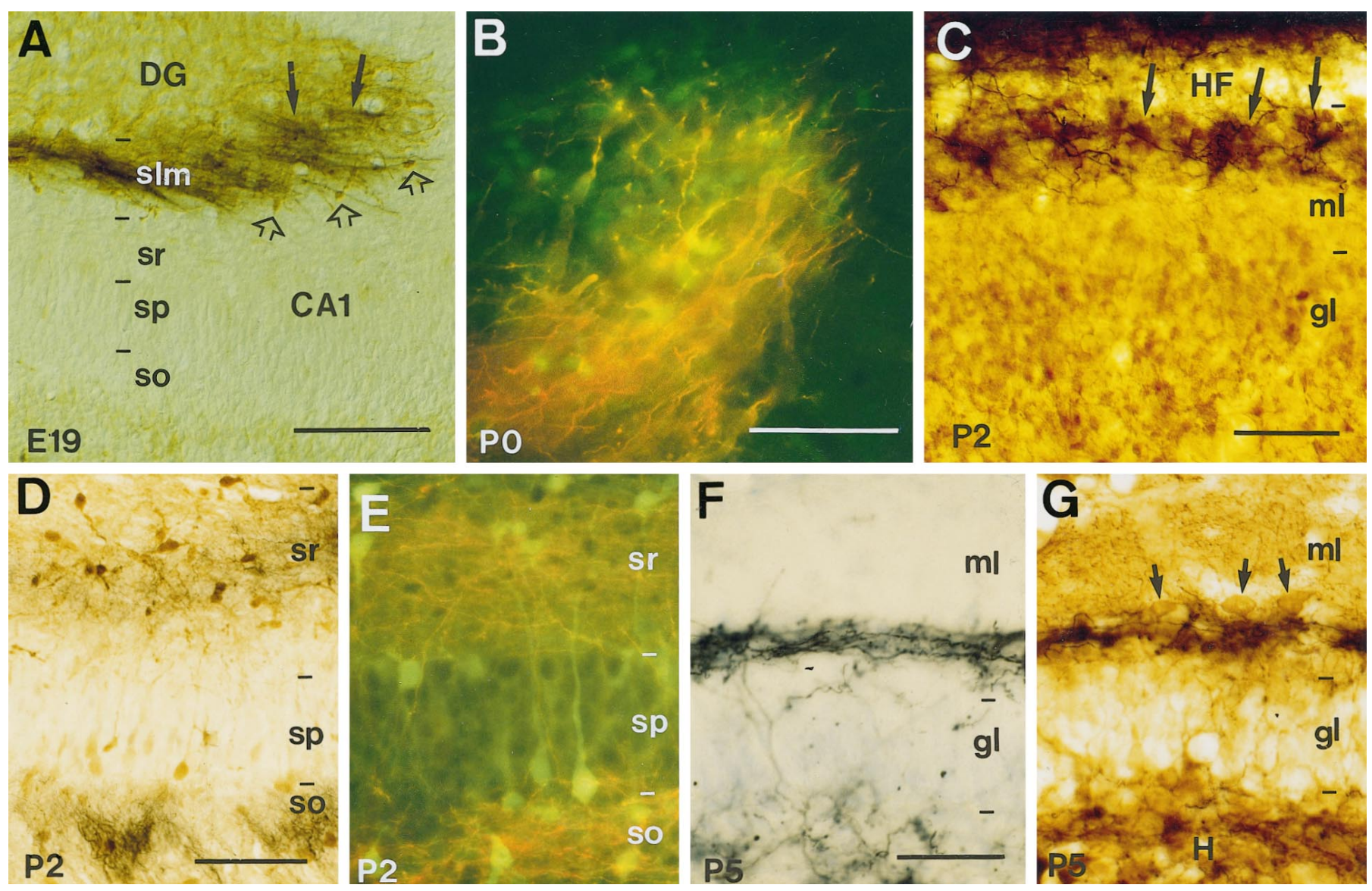

Figure 4. Overlapping distribution of developing hippocampal afferents and pioneer neurons in the hippocampus. $A$, Fascicles of entorhinal axons (black arrows) traced with biocytin overlap with Cajal-Retzius cells in the stratum lacunosum-moleculare identified by calretinin immunostaining (brown open arrows) at E19. B, High-power fluorescence photomicrograph shows entorhinal axons (red) intermingled with calretinin-positive Cajal-Retzius cells (green) at $\mathrm{P} 0$ in the stratum lacunosum-moleculare of the $\mathrm{CA} 3$ region. $C$, In the dentate gyrus, ingrowing entorhinal axons (black) at P2 are restricted to the outer molecular layer (close to the $H F$ ), forming patches (arrows) around the clusters of Cajal-Retzius cells (brown) in this layer. $D$, E, Photomicrographs show that commissural fibers traced with biocytin at $\mathrm{P} 2(D$, black; $E$, red $)$ arborize in the stratum oriens and in the stratum radiatum, where calbindin-positive neurons $(D$, brown; E, green) are located. $F, G$, In the dentate gyrus, commissural axons (black) are restricted to the inner molecular layer at P5, where they overlap with GABA-positive neurons (brown; arrows in $G$ ). The section in $F$ was slightly stained with thionin. Sections were photographed under Nomarski $(A, C, D, F, G)$ or epifluorescence $(B, E)$ optics. Scale bars: $A, 300 \mu \mathrm{m} ; B$ and $E, C, F$ and $G, 50 \mu \mathrm{m} ; D, 100 \mu \mathrm{m}$. $D G$, dentate gyrus; $g l$, granular layer; $H$, hilus; $H F$, hippocampal fissure; $m l$, molecular layer; $s l m$, stratum lacunosum-moleculare; $s o$, stratum oriens; $s p$, stratum pyramidale; $s r$, stratum radiatum.

moleculare were established on calretinin-positive processes and perikarya corresponding to Cajal-Retzius cells (Fig. 6A). This value is likely to represent an underestimation because not all calretinin-immunoreactive processes could be labeled by preembedding immunostaining. The percentage of entorhinal boutons in synaptic contact with calretinin-positive elements decreased to $28 \%$ at P5 and to $3 \%$ in the adult (Fig. 6A).

To analyze the targets of developing commissural axons, we combined anterograde tracing of biocytin visualized by a DAB reaction and postembedding immunogold staining for GABA. Synapses made by commissural fibers in the stratum radiatum at P2 were also relatively rare at P2. As for entorhinal axons, biocytin-labeled commissural axons established asymmetric synaptic contacts (Fig. 5C,D). At these early postnatal stages, most GABA-immunoreactive profiles were dendrites and perikarya, but a few GABA-positive axon terminals forming symmetric synapses were recognized (data not shown). As reported in other studies (Somogyi et al., 1985), immunogold particles were frequently associated with diverse cell membranes and mitochondria (Fig. $5 B, C$ ). At P2, up to $61 \%$ of biocytin-labeled commissural synapses in the stratum radiatum were on GABA-positive elements (Fig. $6 B$ ). This value decreased to $52 \%$ at P5. In the adult hippocampus, GABA-immunoreactive targets of commissural axon terminals represented less that $4 \%$ (Fig. $6 B$ ). Taken together, the above findings show that Cajal-Retzius cells are main transient synaptic targets for ingrowing entorhinal afferents in the stratum lacunosum-moleculare and that early commissural axons prefer GABA-positive neurons as targets instead of the far more numerous pyramidal cell dendrites that are present in the stratum radiatum. Later in development, most pioneer neurons disappear, and synaptogenesis takes place onto the late-maturing principal cells, pyramidal neurons, and dentate granule cells.

\section{DISCUSSION}

In the present study, we have shown that the prospective hippocampus contains two distinct populations of pioneer neurons, namely Cajal-Retzius cells and GABA-positive neurons, which are arranged from very early stages in different, nonoverlapping sublayers in the marginal zone. These distinct subsets of pioneer neurons form early layer-specific scaffolds that are used as guides 

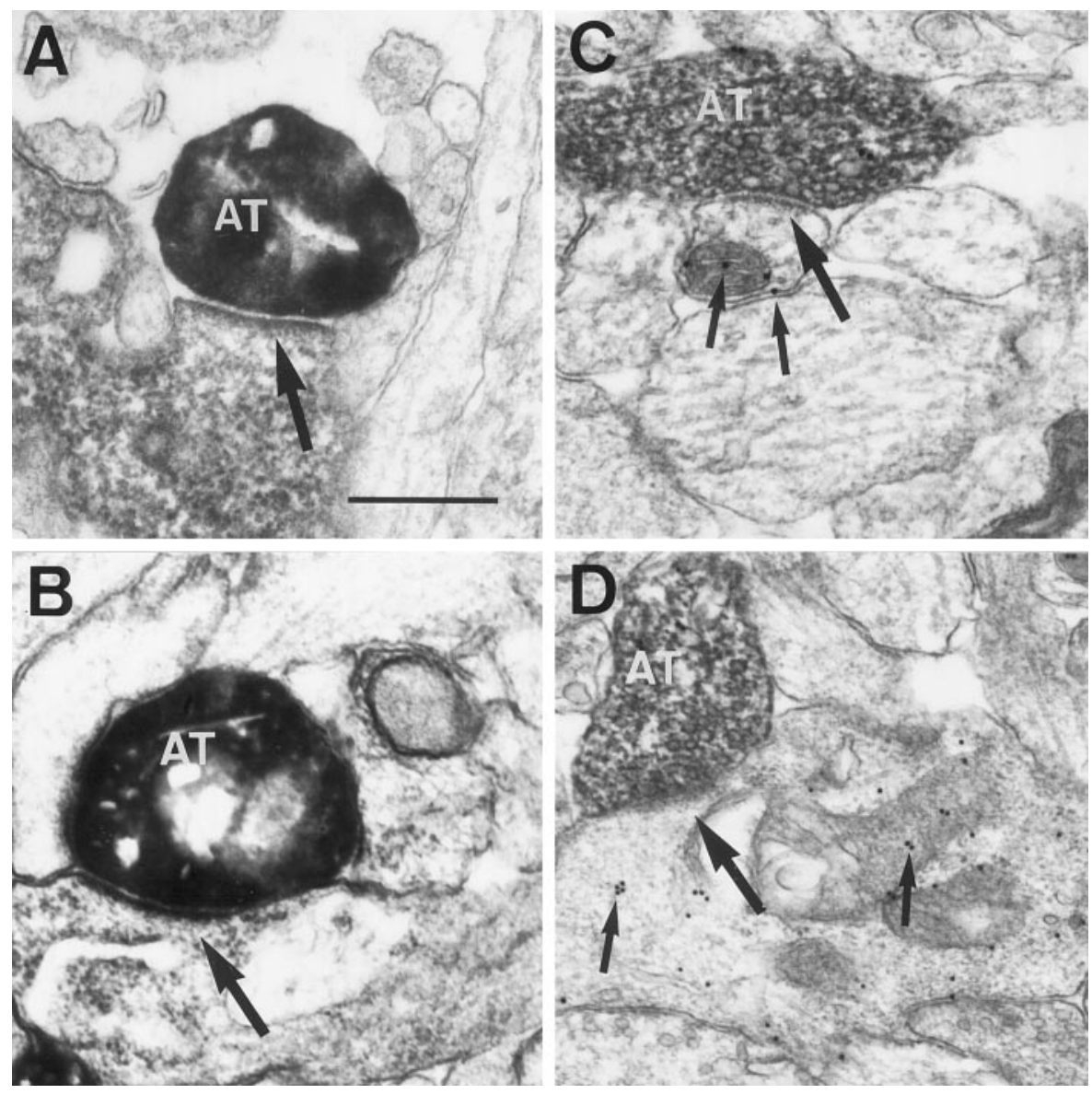

Figure 5. Cajal-Retzius cells and GABApositive neurons are transient synaptic targets of entorhinal and commissural axons. $A, B$, Electron micrographs show biocytin-labeled entorhinal axon terminals $(A T)$ at $\mathrm{P} 0$ in asymmetric synaptic contact (arrows) with the dendrites of Cajal-Retzius cells immunostained for calretinin. Biocytin-positive boutons are identified by the homogenous, electron-dense reaction product (DAB-nickel), whereas calretinin immunostaining shows a granular, less dense precipitate (DAB). $C, D$, Biocytin-positive commissural axon terminals $(A T)$ at $\mathrm{P} 2(D)$ and $\mathrm{P} 5(C)$ establish asymmetric synaptic contacts (large arrows) with GABA-positive dendrites identified by the presence of gold particles (small arrows). Scale bar, $0.4 \mu \mathrm{m}$.
A

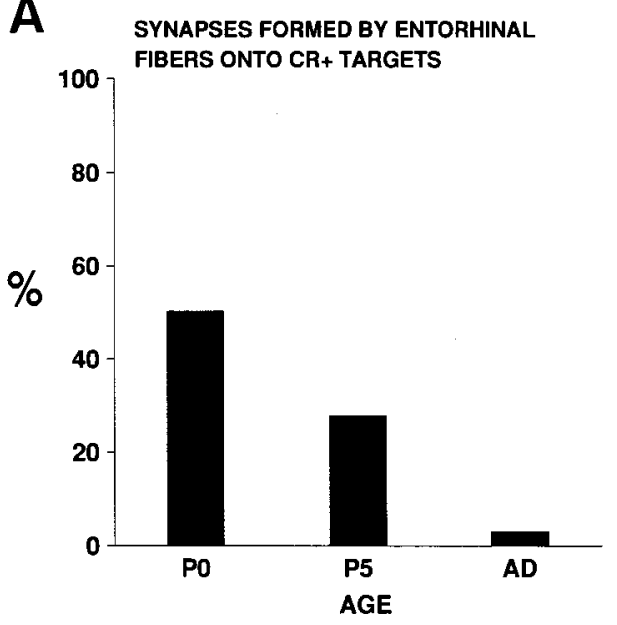

B

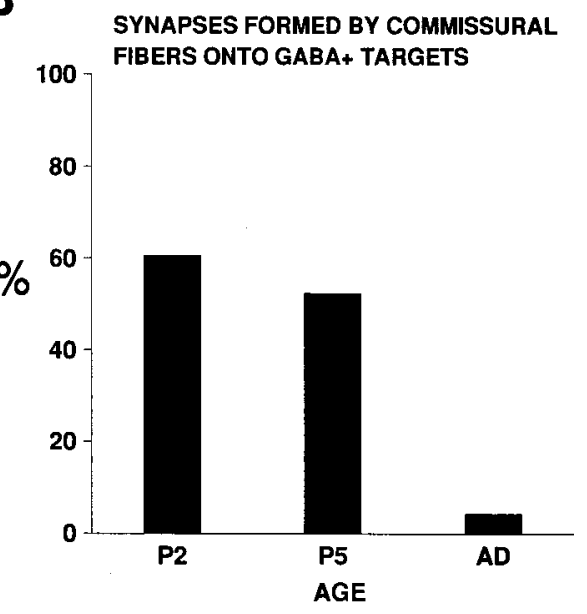

Figure 6. Percentage of entorhinal $(A)$ and commissural $(B)$ boutons that are in synaptic contact on calretinin-positive Cajal-Retzius cells and on GABA-positive elements at different postnatal stages. $A D$, Adult; $C R$, Cajal-Retzius. or "blueprints" for the ingrowth and layer-specific targeting of entorhinal and commissural/associational afferents. Developing hippocampal afferents are not only tightly related spatially to distinct subsets of pioneer neurons but also form synaptic contacts preferentially with them. Such a precise sequence of developmental events strongly indicates that these pioneer neurons participate in the normal development of hippocampal connections (Fig. 7). This conclusion is supported by an earlier study reporting that the laminar specification of hippocampal connections does not depend on the temporal order of fiber arrival (Frotscher and Heimrich, 1993) and by our parallel study showing that the ablation of Cajal-Retzius cells in organotypic slice cocultures prevents the ingrowth and formation of entorhinohippocampal connections in vitro (Del Río et al., 1997). Thus, we propose here a developmental mechanism by which different afferents could be targeted to distinct dendritic domains of the same neurons, thereby forming a layer-specific pattern of connectivity (Fig. 7).

What is the significance of this process? In the murine hippocampus, neurogenesis of pyramidal neurons peaks on E14-E15 in the CA3 region and on E14-E16 in the CA1 subfield (Caviness, 1973; Soriano et al., 1986, 1989). Thus, at the time of afferent ingrowth (e.g., E15-E17 for entorhinal axons), most 
PERINATAL DEVELOPMENT

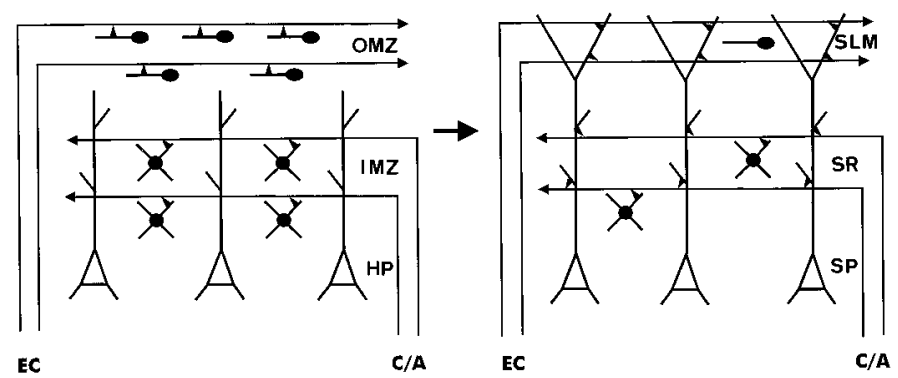

Figure 7. Schematic representation summarizing the main findings of the present study. At late embryonic (E16-E19) and early postnatal stages, developing hippocampal afferents invade the target hippocampus in a layer-specific manner. These ingrowing fibers overlap with CajalRetzius cells in the stratum lacunosum-moleculare and with GABApositive neurons in the stratum radiatum and establish transient synaptic contacts with them. At later postnatal stages and in the adult, most Cajal-Retzius cells and approximately half the population of GABApositive neurons disappear, and hippocampal afferents form synaptic contacts with the principal pyramidal cells. $I M Z$, Inner marginal zone; $O M Z$, outer marginal zone; $S L M$, stratum lacunosum-moleculare; $S P$, stratum pyramidale; $S R$, stratum radiatum; $C / A$, commissural/associational fibers; $E C$, entorhinal cortex axons; $H P$, hippocampal plate.

target pyramidal neurons are still proliferating or migrating in the intermediate zone, which virtually eliminates their participation in the targeting of hippocampal afferents to the upper marginal zone. Indeed, considering that a few pyramidal neurons are already positioned at these (or immediately subsequent) stages in the pyramidal cell layer, it is unlikely that distinct recognition cues could be segregated in a segment-specific manner over the membranes of pyramidal cell dendrites, which at this time are undergoing rapid remodeling and growth. The early ingrowth and synaptogenesis of hippocampal afferents, in turn, is likely to be needed to regulate other aspects of hippocampal development and maturation (Mattson et al., 1988; Frotscher et al., 1995). A similar principle might operate in the development of laminated connections in other brain regions such as the optic tectum (e.g., Cheng et al., 1995; Drescher et al., 1995; Yamagata et al., 1995).

The molecules involved in the ingrowth, layer-specific targeting and specification of hippocampal circuits are unknown. In a previous study, we have shown that the extracellular matrix protein reelin regulates collateral branching and elongation of entorhinal axons, although it is not essential for the ingrowth of developing entorhinal afferents (Del Río et al., 1997). Similarly, recent analysis of the development of entorhinal and commissural projections to the hippocampus of trkB- and trkC-deficient mice indicates that neurotrophin signaling is not essential either for the ingrowth or for the layer-specific targeting of hippocampal afferents (A. Martínez, S. Alcántara, J. A. Del Río, V. Borrell, M. Barbacid, I. Silos-Santiago, and E. Soriano, unpublished observations), which is in agreement with a recent study in the optic tectum (Inoue and Sanes, 1997). However, consistent with current views on neurotrophin action in development (Cabelli et al., 1995, 1997; Cohen-Cory and Fraser, 1995; Bonhoeffer, 1996; Inoue and Sanes, 1997), both TrkB and TrkC receptors influence the branching and maturation of hippocampal afferents. The laminar precision shown by developing hippocampal axons from the earliest invasion of the target region together with their tight relationships with pioneer neurons suggest that, as in other brain regions, both chemoattractant and repulsive factors, either diffusible or membrane-bound, may play a role (Goodman and Shatz, 1993; Kennedy et al., 1994; Serafini et al., 1994; Cheng et al., 1995; Drescher et al., 1995; Kennedy and Tessier-Lavigne, 1995; Matthes et al., 1995; Messersmith et al., 1995; Chan et al., 1996; Flenniken et al., 1996; Keino-Masu et al., 1996). In addition, some extracellular matrix proteins, such as reelin, and adhesion molecules have also been implicated in the lamina-specific connectivity in the brain (Del Río et al., 1997; Inoue and Sanes, 1997). Some of these cues are likely to be expressed by the present pioneer neurons. Recent studies have reported, in fact, that developing hippocampal tissue prevents the axonal outgrowth from neocortical explants (Halloran and Kalil, 1996) and that several eph-receptors and ligands are highly expressed in the developing hippocampus (Gao et al., 1996; Zhang et al., 1996). Also, the phenotype of both netrin-1 and deleted in colorectal cancer $(D C C)$ null-mutant mice, with complete absence of the hippocampal commissure, suggests the participation of netrin-1 in the development of hippocampal connections (Serafini et al., 1996; Fazeli et al., 1997).

Our cell counts on both BrdU- and neural antigenimmunoreacted sections show that $\sim 75 \%$ of Cajal-Retzius cells disappear by cell death in the hippocampus, which is consistent with the sparsity of neurons in the adult stratum lacunosummoleculare (Freund and Buzsaki, 1996). However, the disappearance of Cajal-Retzius cells occurs slightly later in the hippocampus than in the neocortex (Derer and Derer, 1992; Del Río et al., 1995), consistent with the relatively late development of the hippocampus and dentate gyrus. In contrast, $\sim 40-50 \%$ of the early GABA-positive pioneer neurons located in the stratum radiatum persist at adult stages. This is also consistent with the abundant population of GABA-positive neurons present in the adult stratum radiatum (Freund and Buzsaki, 1996) and with birthdating analysis showing that most such neurons are generated early (Soriano et al., 1989). Although discovered more than one century ago, the functions of Cajal-Retzius cells in cortical development have remained elusive (Marín-Padilla, 1972, 1978, 1988; Del Río et al., 1995). Recently, studies reporting that reelin, the gene product affected in the reeler mutation, is expressed by Cajal-Retzius cells have strongly indicated a role for these neurons in migration (D'Arcangelo et al., 1995; Hirotsune et al., 1995; Ogawa et al., 1995). The present findings and those of our parallel study in vitro (Del Río et al., 1997) show that CajalRetzius cells are also involved in axonal growth and target-layer selection, at least in the hippocampal region. This finding supports the notion that these pioneer neurons subserve different and essential functions in corticogenesis (Marín-Padilla, 1988).

The role proposed here for the pioneer neurons in the marginal zone of the hippocampus, i.e., target selection by developing afferents, is strikingly similar to that subserved in the neocortex by subplate neurons for thalamocortical axons (Rakic, 1976, 1977; McConnell et al., 1989; Ghosh et al., 1990; Allendoerfer and Shatz, 1994). Many studies have indicated previously that in the hippocampus the subplate is poorly developed, whereas the marginal zone contains many more neurons than does the subplate (e.g., Stensaas, 1967; Nowakowski and Rakic, 1979; Soriano et al., 1994). The opposite holds true for the developing neocortex, in which the marginal zone forms a very thin layer, whereas the subplate, especially in carnivores and primates, is one of the most prominent layers (Marín-Padilla, 1978; Kostovic and Rakic, 1980, 1990; Chun et al., 1987; Allendoerfer and Shatz, 1994). Given the parallel functional significance of the subplate and marginal zone, it is tempting to speculate that relative differences in the abun- 
dance and location of the two main groups of pioneer neurons (marginal zone neurons vs subplate cells) could be essential in directing the route of entry and pattern of termination of cortical afferents and the resulting cortical organization. It is noteworthy, for instance, than in the neocortex of the reeler mutant mouse, in which subplate neurons are located directly underneath the cortical surface, thalamocortical axonal tracts perforate the cortical gray matter to reach the subplate neurons and then descend toward their target neurons (Molnár and Blakemore, 1995). Thus, in conjunction with current views of cortical evolution (Rakic, 1988; Northcutt and Kaas, 1995), major developmental differences in the preplate populations may be a relevant parameter to understand cortical ontogeny and phylogeny, especially neo- versus archicortical specification and evolution.

\section{REFERENCES}

Allendoerfer KL, Shatz CJ (1994) The subplate, a transient neocortical structure: its role in the development of connections between thalamus and cortex. Annu Rev Neurosci 17:185-218.

Amaral DG, Witter MP (1995) Hippocampal formation. In: The rat nervous system, 2nd Edition (Paxinos G, ed), pp 443-493. New York: Academic.

Bentley D, Keshishian H (1982) Pioneer neurons and pathways in insect appendages. Trends Neurosci 5:354-358.

Blackstad TW (1956) Commissural connections of the hippocampal region in the rat, with special reference to their mode of termination. J Comp Neurol 105:417-537.

Bonhoeffer T (1996) Neurotrophins and activity-dependent development of the neocortex. Curr Opin Neurobiol 6:119-126.

Cabelli RJ, Hohn A, Shatz CJ (1995) Inhibition of ocular dominance column formation by infusion of NT4/5 or BDNF. Science 267:1662-1666.

Cabelli RJ, Shelton DL, Segal RA, Shatz CJ (1997) Blockade of endogenous ligands of TrkB inhibits formation of ocular dominance columns. Neuron 19:63-76.

Caviness VS (1973) Time of neuron origin in the hippocampus and dentate gyrus of normal and reeler mutant mice: an autoradiographic analysis. J Comp Neurol 151:113-120.

Chan SSY, Zheng H, Wu M, Wilk R, Killeen MT, Hedgehock EM, Culotti JG (1996) UNC-40, a C. elegans homolog of DCC (deleted in colorectal cancer), is required in motile cells responding to UNC-6 netrin cues. Cell 87:187-195.

Cheng H-J, Nakamoto M, Bergemann AD, Flanagan JG (1995) Complementary gradients in expression and binding of ELF-1 and Mek 4 in development of the topographic retinotectal projection map. Cell 82:371-381.

Chun JJM, Nakamura NJ, Shatz CJ (1987) Transient cells of the developing mammalian telencephalon are peptide inmunoreactive neurons. Nature 235:617-619.

Cohen-Cory S, Fraser SE (1995) Effects of brain-derived neurotrophic factor on optic axon branching and remodeling in vivo. Nature 378:192-196.

Colamarino SA, Tessier-Lavigne M (1995) The axonal chemoattractant netrin-1 is also a chemorepellent for trochlear motor axons. Cell 81:621-629.

Culotti JG, Kolodkin AL (1996) Functions of netrins and semaphorins in axon guidance. Curr Opin Neurobiol 6:81-88.

D’Arcangelo G, Miao GG, Chen S-C, Soares H, Morgan JI, Curran T (1995) A protein related to extracellular matrix proteins deleted in the mouse mutant reeler. Nature 374:719-723.

D’Arcangelo G, Nakajima K, Ogawa M, Mikoshiba K, Curran T (1997) Reelin is a secreted glycoprotein recognized by the CR-50 monoclonal antibody. J Neurosci 17:23-31.

Del Río JA, Martínez A, Fonseca M, Auladell C, Soriano E (1995) Glutamate-like immunoreactivity and fate of Cajal-Retzius cells in the murine cortex as identified with calretinin antibody. Cereb Cortex 5:13-21.

Del Río JA, Heimrich B, Borell V, Forster E, Alcantara S, Nahajima K, Miyata T, Ogawa M, Mikoshiba K, Derer P, Frotscher M, Soriano E (1997) A role for Cajal-Retzius cells and reelin in the development of hippocampal connections. Nature 385:70-74.

Derer P, Derer M (1992) Development and fate of Cajal-Retzius cells in vivo and in vitro. In: Development of the central nervous system in the vertebrates, pp 113-128. New York: Plenum.

Drescher U, Kremoser C, Handwerker C, Loschinger J, Noda M, Bonhoeffer F (1995) In vitro guidance of retinal ganglion cell axons by RAGS, a $25 \mathrm{kDa}$ tectal protein related to ligands for Eph receptor tyrosine kinases. Cell 82:359-370.

Fazeli A, Dickinson SL, Hermiston ML, Tighe RV, Steen RG, Small CG, Stoeckli ET, Keino-Masu K, Masu M, Rayburn H, Simson J, Bronson RT, Gordon JI, Tessier-Lavigne M, Weinberg RA (1997) Phenotype of mice lacking functional deleted in colorectal cancer (Dcc) gene. Nature 386:796-804.

Flenniken AM, Gale NW, Yancopoulos GD, Wilkinson DG (1996) Distinct and overlapping expression patterns of ligands for Eph-related receptor tyrosine kinases during mouse embryogenesis. Dev Biol 179:382-401.

Freund TF, Buzsaki G (1996) Interneurons in the hippocampus. Hippocampus 6:347-470.

Frotscher M, Heimrich B (1993) Formation of layer-specific fiber projections to the hippocampus in vitro. Proc Natl Acad Sci USA 90:10400-10403.

Frotscher M, Zafirov S, Heimrich B (1995) Development of identified neuronal types of specific synaptic connections in slice cultures of rat hippocampus. Prog Neurobiol 45:7-28.

Gao PP, Zhang JH, Yokoyama M, Racey B, Dreyfus CF, Black IB, Zhou R (1996) Regulation of topographic projection in the brain: Elf-1 in the hippocamposeptal system. Proc Natl Acad Sci USA 93:11161-11166.

Ghosh A, Shatz CJ (1992) Involvement of subplate neurons in the formation of ocular dominance columns. Science 255:1441-1443.

Ghosh A, Antonini A, McConnell SK, Shatz CJ (1990) Requirement for subplate neurons in the formation of thalamocortical connections. Nature 347:179-181.

Goodman CS, Shatz CJ (1993) Developmental mechanisms that generate precise patterns of neuronal connectivity. Neuron [Suppl] 10:77-98.

Gulyás AI, Miles R, Sik A, Toth K, Tamamaki N, Freund TF (1993) Hippocampal pyramidal cells excite inhibitory neurons through a single release site. Nature 366:683-687.

Halloran MC, Kalil K (1996) Selective neurite outgrowth of cultured cortical neurons on specific regions of brain cryostat sections. J Comp Neurol 371:72-84.

Hirotsune S, Takahara T, Sasaki K, Hirose K, Yoshiki A, Ohashi T, Kusakabe M, Murakami Y, Muramutsu M, Watanabe S, Nakao K, Katsuki M, Hayashizaki Y (1995) The reeler gene encodes a protein with an EGF-like motif expressed by pioneer neurons. Nat Genet 10:77-83.

Hjorth-Simonsen A, Jeune B (1972) Origin and termination of the hippocampal perforant path in the rat studied by silver impregnation. J Comp Neurol 144:215-232.

Inoue A, Sanes JR (1997) Lamina-specific connectivity in the brain: regulation by $N$-cadherin, neurotrophins, and glycoconjugates. Science 276:1428-1431.

Katz LC, Shatz CJ (1996) Synaptic activity and the construction of cortical circuits. Science 274:1133-1138.

Keino-Masu K, Masu M, Hinck L, Leonardo ED, Chan S S-Y, Culotti JG, Tessier-Lavigne M (1996) Deleted in colorectal cancer (DCC) encodes a netrin receptor. Cell 87:175-185.

Kennedy TE, Tessier-Lavigne M (1995) Guidance and induction of branch information in developing axons by target-derived diffusible factors. Curr Opin Neurobiol 5:83-90.

Kennedy TE, Serafini T, de la Torre JR, Tessier-Lavigne M (1994) Netrins are diff usible chemotropic factors for commissural axons in the embryonic spinal cord. Cell 78:425-435.

Kostovic I, Rakic P (1980) Cytology and time of origin of interstitial neurons in the white matter in infant and adult human and monkey telencephalon. J Neurocytol 9:219-242.

Kostovic I, Rakic P (1990) Developmental history of the transient subplate zone in the visual and somatosensory cortex of the macaque monkey and human brain. J Comp Neurol 297:441-470.

Marín-Padilla M (1972) Prenatal ontogenic history of the principal neurons of the neocortex of the cat (Felix domestica). A Golgi study. II. Developmental differences and their significances. Z Anat Entwicklungsgesch 136:125-142.

Marín-Padilla M (1978) Dual origin of the mammalian neocortex and evolution of the cortical plate. Anat Embryol 152:109-126.

Marín-Padilla M (1988) Early ontogenesis of the human cerebral cortex. 
In: Cerebral cortex, Vol VII, Development and maturation of the cerebral cortex (Peters A, Jones EG, eds), pp 1-30. New York: Plenum.

Matthes DJ, Sink H, Kolodkin AL, Goodman CS (1995) Semaphorin II can function as a selective inhibitor of specific synaptic arborizations. Cell 81:631-639.

Mattson MP, Lee RE, Adams ME, Guthrie PB, Kater SB (1988) Interactions between entorhinal axons and target hippocampal neurons: a role for glutamate in the development of hippocampal circuitry. Neuron $1: 865-876$.

McConnell SK, Ghosh A, Shatz CJ (1989) Subplate neurons pioneer the first axon pathway from the cerebral cortex. Science 245:978-982.

Messersmith EK, Leonardo ED, Shatz CJ, Tessier-Lavigne M (1995) Semaphorin III can function as a selective chemorepellent to pattern sensory projection in the spinal cord. Neuron 14:949-959.

Molnár Z, Blakemore C (1995) How do thalamic axons find their way to the cortex? Trends Neurosci 18:389-397.

Northcutt RG, Kaas JH (1995) The emergence and evolution of the mammalian neocortex. Trends Neurosci 18:373-379.

Nowakowski RS, Rakic PJ (1979) The mode of migration of neurons to the hippocampus; a Golgi and electron microscopic analysis in foetal rhesus monkey. J Neurocytol 8:697-718.

Ogawa M, Miyata T, Nakajima K, Yagyu K, Seike M, Ikenaka K, Yamamoto H, Mikoshiba K (1995) The reeler gene-associated antigen on Cajal-Retzius neurons is a crucial molecule for laminar organization of cortical neurons. Neuron 14:899-912.

Raisman G, Cowan WM, Powell TPS (1965) The extrinsic afferent, commissural and association fibers of the hippocampus. Brain 88:963-996.

Rakic P (1976) Prenatal genesis of connections subserving ocular dominance in the rhesus monkey. Nature 261:467-471.

Rakic P (1977) Prenatal development of the visual system in the rhesus monkey. Philos Trans R Soc Lond [Biol] 278:245-260.

Rakic P (1988) Specification of cerebral cortical areas. Science 241:170-176

Serafini T, Kennedy TE, Galko MJ, Mirzayan C, Jessel TM (1994) The netrins define a family of axon outgrowth promoting proteins homologous to C. elegans UNC-6. Cell 78:409-424.

Serafini T, Colamarino SA, Leonardo ED, Wang H, Beddington R, Skarnes WC, Teisser-Lavinge M (1996) Netrin-1 is required for commissural axon guidance in the developing vertebrate nervous system. Cell 87:1001-1014.

Slotnick B, Leonard CM (1975) A stereotaxic atlas of the albino mouse forebrain. Rockville, MD: United States Department of Health, Education, and Welfare.
Somogyi P, Hodgson AJ, Chubb I, Penke B, Erdei A (1985) Antisera to gamma-aminobutyric acid. II. Immunocytochemical applications to the central nervous system. J Histochem Cytochem 33:240-248.

Soriano E, Del Río JA (1991) Simultaneous immunocytochemical visualization of bromodeoxyuridine and neural tissue antigens. J Histochem Cytochem 39:255-263.

Soriano E, Cobas A, Fairén A (1986) Asynchronism in the neurogenesis of GABAergic and non-GABAergic neurons in the mouse hippocampus. Dev Brain Res 30:88-92.

Soriano E, Cobas A, Fairén A (1989) Neurogenesis of glutamic acid decarboxylase immunoreactive cells in the hippocampus of the mouse. I. Regio superior and regio inferior. J Comp Neurol 281:586-602.

Soriano E, Del Río JA, Martínez A, Supèr H (1994) Organization of the embryonic and early postnatal murine hippocampus. I. Immunocytochemical characterization of neuronal populations in the subplate and marginal zone. J Comp Neurol 342:571-595.

Sretavan DW (1993) Pathfinding at the mammalian optic chiasm. Curr Opin Neurobiol 3:45-52.

Stensaas LJ (1967) The development of hippocampal and dorsolateral pallial regions of the cerebral hemisphere in fetal rabbits. III. Twentynine millimeter stage, marginal lamina. J Comp Neurol 130:149-162.

Supèr H, Soriano E (1994) The organization of the embryonic and early postnatal murine hippocampus. II. Development of entorhinal, commissural, and septal connections studied with the lipophilic tracer DiI. J Comp Neurol 344:101-120.

Tessier-Lavigne M, Goodman CS (1996) The molecular biology of axon guidance. Science 274:1123-1132.

Valverde F, Facal-Valverde MV (1987) Transitory population of cells in the temporal cortex of kittens. Brain Res 429:283-288.

Valverde F, López-Mascaraque L, Santacana M, De Carlos JA (1995) Persistence of early-generated neurons in the rodent subplate: assessment of cell death in neocortex during the early postnatal period. J Neurosci 15:5014-5024.

Wang LC, Dani J, Godement P, Marcus RC, Mason CA (1995) Cell-cell interactions influence survival and differentiation of purified Purkinje cells in vitro. Neuron 12:243-260.

Yamagata M, Herman J-P, Sanes JR (1995) Laminar specific expression of adhesion molecules in developing chick optic tectum. J Neurosci 15:4556-4571.

Zhang JH, Cerretti DP, Yu T, Flanagan JG, Zhou R (1996) Detection of ligands in regions anatomically connected to neurons expressing the Eph receptor Bsk: potential roles in neuron-target interaction. J Neurosci 16:7182-7192. 